\title{
NORTHWARD RANGE EXTENSION FOR THE GRAY TREEFROG IN WEST- CENTRAL MANITOBA
}

\section{PETER TAYLOR, P.O. Box 597, Pinawa, MB, R0E 1L0. taylorp@granite.mb.ca>}

This article describes a northward range extension for the Gray Treefrog (Hyla versicolor) up to the 53rd parallel, about $120 \mathrm{~km}$ beyond the previously documented limit in Manitoba. ${ }^{2}$ The range extension is based on frogs heard calling between 1993 and 2006 near
Provincial Trunk Highways (Hwy) 6 and 60 , as shown on the accompanying map (Figure 1). While the records were not confirmed by sight, I am very familiar with the slow, pulsing trill of this frog, which is abundant near my home at Pinawa in southeastern Manitoba. ${ }^{4}$

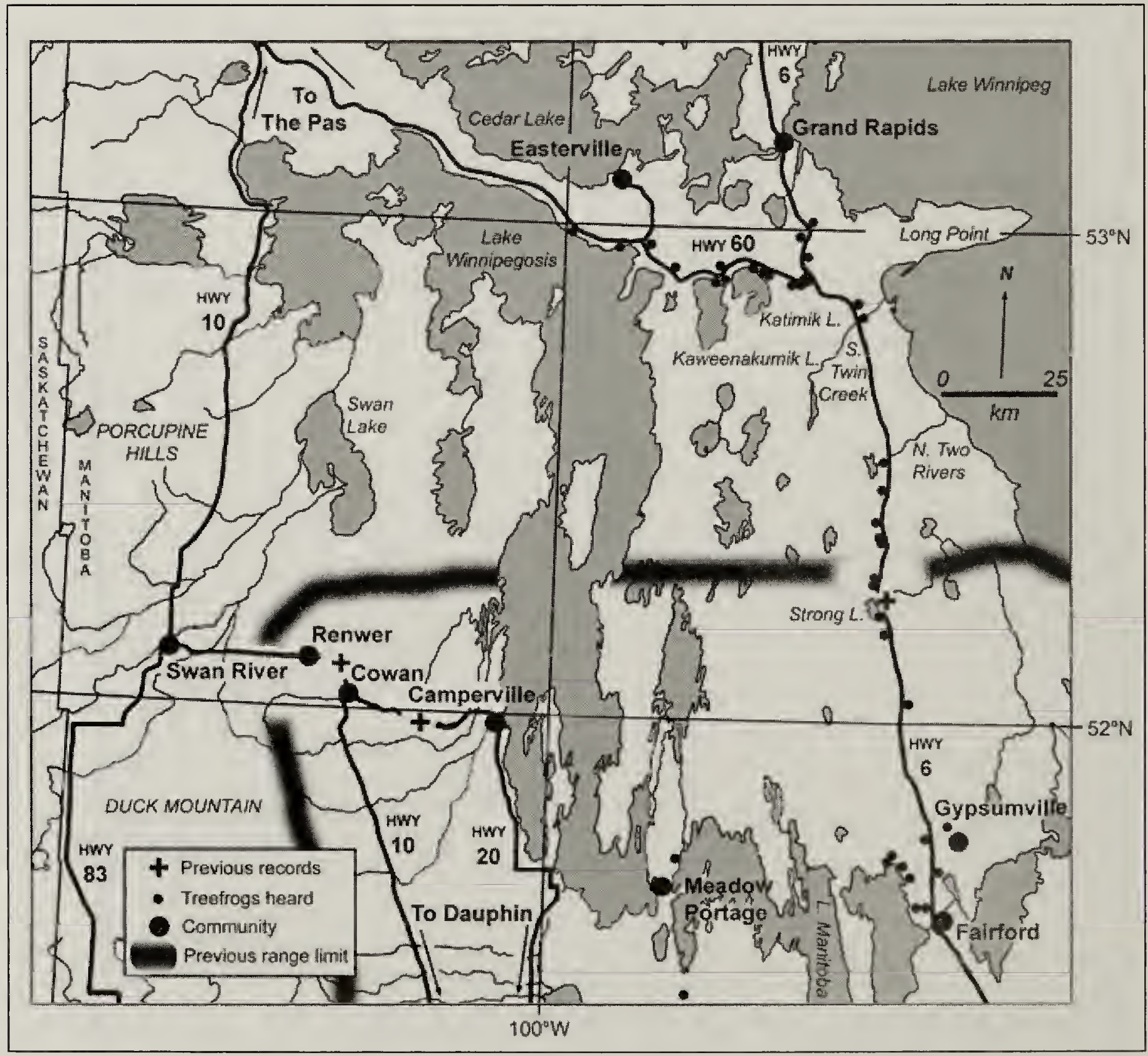

Figure 1. Map of west-central Manitoba, showing locations of calling Gray Treefrogs heard between 1993 and 2006, plus the three most northerly specimen records and the previously estimated range limit. ${ }^{2,3}$ 
The Gray Treefrog (see inside front cover) and Cope's Gray Treefrog $(H$. chrysoscelis) are widespread eastern North American species whose ranges overlap and extend as far northwest as Manitoba. ${ }^{2}$ Though indistinguishable in appearance, they differ genetically, with $H$. versicolor having twice as many chromosomes ("tetraploid") as $H$. chrysoscelis ("diploid"). Fortunately, the calls of these two species can be distinguished, Cope's Gray Treefrog having a faster trill. ${ }^{2}$ Cope's Gray Treefrog has a slightly more southerly distribution than the Gray Treefrog and, in Manitoba, it occurs mostly to the south of Lakes Manitoba and Winnipeg. ${ }^{2}$ The published range of the Gray Treefrog extends well into the Interlake region (the area bounded by Lake Winnipeg to the east and Lakes Manitoba and Winnipegosis to the west), and also west of Lakes Manitoba and Winnipegosis. ${ }^{2}$

\section{Previous Records}

Bill Preston, former Curator of Reptiles, Amphibians and Fishes at The Manitoba Museum [formerly Manitoba Museum of Man and Nature], included detailed distribution maps of specimens and sightings for all the species described in his handbook on the amphibians and reptiles of Manitoba. ${ }^{2}$ He delineated the Gray Treefrog's range limit with specimen records by F.R. Cook near Camperville and by F.W. Schueler north of Fairford, plus observations by Bill Walley and himself near Dauphin. ${ }^{2}$

Further details, including map coordinates and collection numbers, are provided in an article by Schueler and Ross, who led a joint survey trip to central and northern Manitoba for the National Museum of Natural Sciences (Ottawa, ON) and the Museum of Comparative Zoology (Cambridge, MA) between 18 May and 11 June $1980 .^{3}$
They found Gray Treefrogs sufficiently abundant in the Fairford area on 19 May to obtain a sampling of 82 specimens. ${ }^{3}$ They also found the species at several locations along Hwy 6 north of Fairford, up to a point " $17.4 \mathrm{~km}$ s. of Devils Lake", where three additional specimens were taken. This is at or near Pelican Creek, which flows from Strong Lake to Lake Winnipeg. Schueler and Ross searched unsuccessfully for Gray Treefrogs in the Grand Rapids area on the evening of 20 May 1980, and also found none along Hwy 60 at the end of May. $^{3}$

The location near Strong Lake, and Cook's two specimen locations from the Camperville area, are shown in Figure 1. The latter specimens were obtained along Hwy 20, $18.3 \mathrm{~km}$ w. of Camperville on 19 August 1960 and along Hwy 10, $22.5 \mathrm{~km}$ e. of the Minitonas turnoff, on 8 June $1970 .{ }^{3}$ At a longitude of $100.80 \mathrm{~W}$, this last location is barely $60 \mathrm{~km}$ from the Saskatchewan border.

Additional background information for this article was sought on the distributed data network entitled Species Analyst, a project of the North American Biodiversity Information Network and participating institutions. ${ }^{9}$ This search confirmed the Camperville and Fairford area records noted above, but did not reveal any additional records north of $52^{\circ} \mathrm{N}$.

Records were also sought by contacting several Manitoba naturalists in November 2007. Bill Walley confirmed that Gray Treefrogs are common around Dauphin and in parts of Riding Mountain National Park (south of the area mapped in Figure 1), with calling as early as the second half of May if warm weather prevails. Walter Krivda verified that the species is not known to occur near The Pas (north of the area on Figure 1). Randy Mooi, Curator of Zoology at The Manitoba Museum, confirmed that the 
museum has no records from north of the published range.

\section{Initial Observations}

On 10 occasions between 1991 and 2007 (1991/93/94/97, 2000/02/03/05/06/ $07)$, on various dates from 12 June to 3 July, I visited the Grand Rapids area of west-central Manitoba for periods of a few days to run several Breeding Bird Surveys (BBS). These roadside surveys last from about 4:30 to 9:00 a.m., leaving a lot of time for additional natural history observations as well as a few hours of sleep. Among these observations are a number of records of calling Gray Treefrogs.

The first record involved a single treefrog calling at about 10 a.m. on 2 July 1993 alongside Hwy 60, midway between the access roads to Kaweenakumik Lake (formerly called Kawinaw Lake) and Katimik Lake. This point is $18.7 \mathrm{~km}$ west of Hwy 6; this and all distances below refer to vehicle odometer readings. I reported this observation to Bill Preston, who included it as "Grand Rapids" in an undated, annotated checklist distributed with provincial frog monitoring material in the mid-1990s. It is also mentioned in Weller and Green's checklist of Canadian amphibians. ${ }^{7}$

No treefrogs were heard on subsequent visits in 1994 and 1997 , including a brief search at the above location at 9:50 p.m. on 24 June 1994. Then, while running the Twin Creeks BBS on 19 June 2000, I heard single Gray Treefrogs calling at about 7:30 a.m. alongside Hwy 60 at 9.2 and $10.0 \mathrm{~km}$ west of Hwy 6. At 9:40 a.m., after the BBS was complete, another treefrog was heard near the northeastern shore of Kaweenakumik Lake. Based on experience in southeastern Manitoba, I expected more intense calling in the evening, especially in warm, humid weather. $^{4}$

\section{Intensive Surveys}

The evening of 19 June 2000 appeared perfect for a detailed survey, with an air temperature of about $20 \mathrm{C}$, little wind, an overcast sky, and a suggestion of approaching rain. Sure enough, when I returned at 7:00 p.m., treefrogs were already calling in

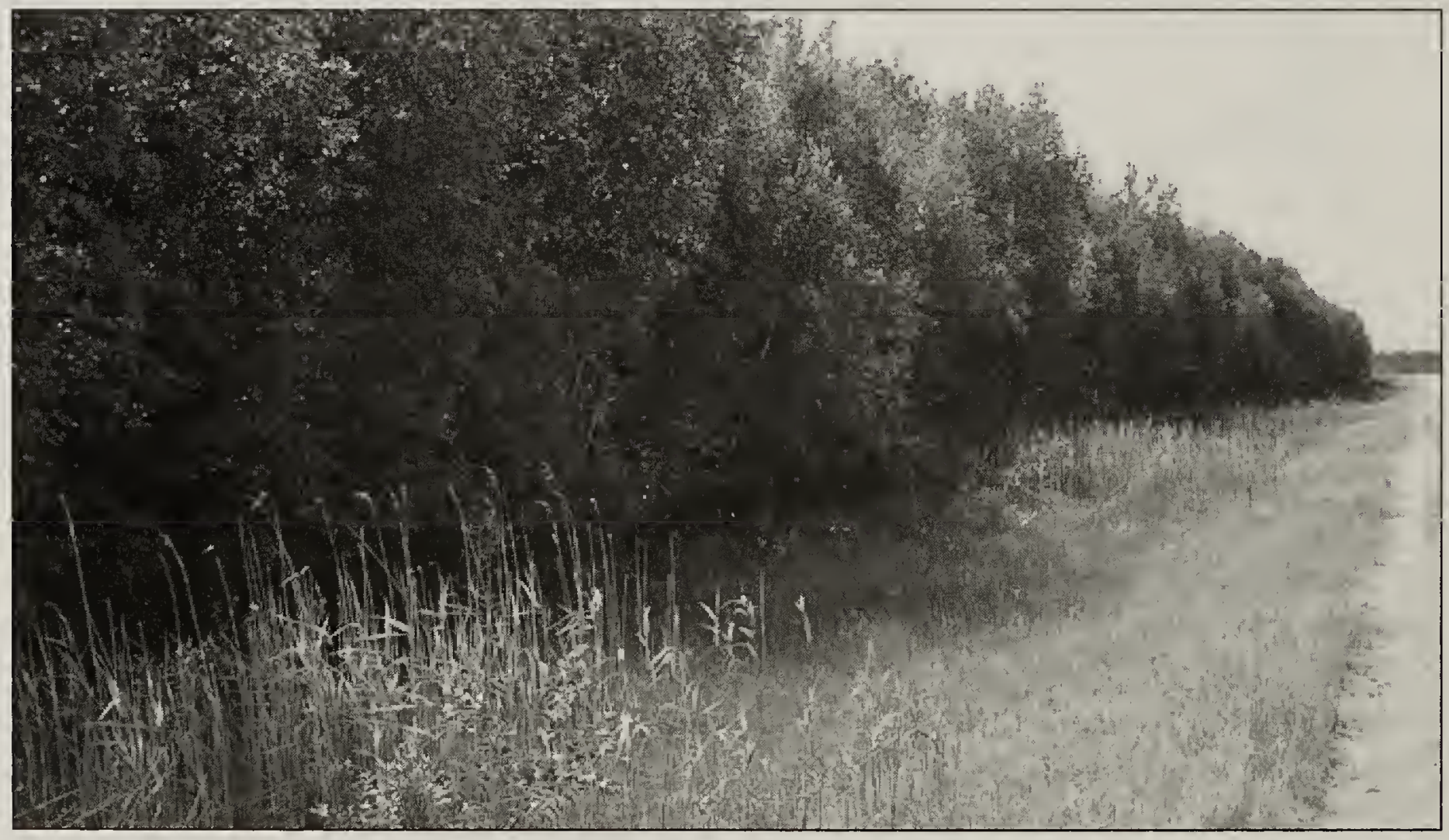

Figure 3. Gray Treefrog habitat alongside Hwy 60, east of Katimik Lake, Manitoba: a dense deciduous thicket adjoining a marshy ditch.

Peter Taylor 
roadside ditches along Hwy 60 , close to the junction of Hwy 6 (52.918N, $99.182 \mathrm{P})$. At least 21 were heard at seven stops along the first $5 \mathrm{~km}$ of Hwy 60 . More were heard at numerous locations from the $9 \mathrm{~km}$ mark to the Katimik Lake access road at $14.4 \mathrm{~km}$, with a particularly strong chorus in a dense aspen-willow-birch thicket at 10 $\mathrm{km}$ (Figure 3). While they seem to show a preference for deciduous stands, treefrogs were also heard in ditches in or near spruce, tamarack, and mixedwood forest.

More treefrogs were calling along the 8.5-km stretch between the access roads to Katimik Lake $(52.930 \mathrm{~N}$, 99.383 $\mathrm{W}$ ) and Kaweenakumik Lake (52.902N, 99.498W), especially at a flooded borrow pit beside a disused lumber camp roughly midway between these points. Some were calling well away from the road, downslope toward Kaweenakumik Lake. At the lakeshore, there was a moderate mixed chorus of Gray Treefrogs and Boreal Chorus Frogs (Pseudacris maculata) in the emergent vegetation, while a few more treefrogs called in the aspen forest nearby.

Another strong chorus of treefrogs was noted at a borrow pit, surrounded by spruce bog but with some deciduous growth nearby, on the north side of Hwy 60 , a further $11.3 \mathrm{~km}$ west of the Kaweenakumik Lake road. Additional scattered observations of small numbers extended to $18 \mathrm{~km}$ west of the Easterville Road (PR 327) junction, or $60 \mathrm{~km}$ from Hwy 6 (52.987N, $99.968 \mathrm{~W})$. I terminated the survey at this point. While returning to Grand Rapids at about 11 p.m., I also heard treefrogs calling at a few spots along Hwy 6 northward to South Morrison Creek (53.060N, 99.225W; apparently not an official name, though in common use).
Similar observations under comparable weather conditions, involving smaller numbers of treefrogs, were made along the same stretches of Hwys 6 and 60 in 2002 and 2005. Starting at about 7 p.m. on 14 June 2002, after first confirming that choruses were underway along the first $10 \mathrm{~km}$ of Hwy 60 from Hwy 6, I surveyed promising spots farther north along Hwy 6 . At least 6 treefrogs were calling at four of nine stops northward to $53.025 \mathrm{~N}, 99.214 \mathrm{~W}$, about $4 \mathrm{~km}$ SSE of the South Morrison Creek crossing. None was heard at several stops farther north, up to and including "North" Morrison Creek (53.084N, 99.232W). Between 5:15 and 9 p.m. on 23 June 2005, despite Force 4 to 6 winds that hampered listening at times, I found treefrogs calling at several locations along Hwy 60 west to the Kaweenakumik Lake area, and along Hwy 6 northward almost to the $53 \mathrm{rd}$ parallel $(52.966 \mathrm{~N}$, 99.177 W).

\section{Additional Observations}

Further incidental observations of calling treefrogs were made on various occasions: (a) while running a BBS route southward along Hwy 6 from North Two Rivers on 20 June 2000 and 18 June 2002; (b) while travelling north to Grand Rapids on the afternoon of 13 June 2002; and (c) while staying at St. Martin Junction (just north of Fairford) on 1214 June 2006 . Finally, single treefrogs were heard $6 \mathrm{~km}$ north and $36 \mathrm{~km}$ south of Meadow Portage on the wet afternoon of 20 June 2000 . All these calling locations are included in Figure 1.

\section{Discussion}

Substantial choruses in 2000, 2002 , and 2005 indicate an established Gray Treefrog population in much of the area surveyed, with breeding activity around mid- to late June under favourable weather conditions. Treefrogs were not 
found in some years, but this was usually due either to cool conditions or to little or no time being spent in suitable areas in the evening. Research by McAlpine et al. near the Gray Treefrog's northeastern range limit in New Brunswick and Maine shows that several years of observation may be needed to define distribution in a given area. Their report was based on searching on 11 dates in six different years between 1980 and 1990. ${ }^{1}$ They noted that "Activity of $H$. versicolor choruses, particularly small choruses, was sensitive to local temperature, wind, and humidity... Local climatic fluctuations and short individual periods in a chorus, combined with the small size of many choruses, may have contributed to the past difficulty in determining the true range of the Gray Treefrog in New Brunswick."

The extreme calling dates of 14 June and 3 July in the present study were constrained by the BBS schedule, and are not necessarily extreme dates for breeding activity. They are remarkably similar, however, to the reported calling dates of 12 June to 5 July in New Brunswick and Maine. ${ }^{1}$ While peak treefrog choruses in southeastern Manitoba (including year-to-year variation) extend from mid-May to early July, the onset of calling may be later in more northerly locations. ${ }^{4}$

When describing a range extension for an inconspicuous organism in a thinly populated region, it is difficult to distinguish an actual range expansion from an increase in knowledge of longstanding distribution. The northern limit of Schueler and Ross's records in the Interlake region of Manitoba may represent a limit of emergence, rather than range, on the relatively early date of 19 May. ${ }^{3}$ Elsewhere in Manitoba, records are sparse east of Lake Winnipeg, west of Lake Winnipegosis, and in the eastern Interlake region. ${ }^{2}$ Recent records from northwestern Ontario, New Brunswick and Maine indicate that the Gray Treefrog's entire northern range limit remains ill-defined. ${ }^{1,6,8}$

The study by McAlpine et al. filled in part of the gap between the Gray Treefrog's contiguous range and a disjunct population near Fredericton, NB. ${ }^{1}$ They noted: "Few sites were represented by undisturbed habitat and most breeding ponds had been created by road construction or the excavation of gravel... the species' range and abundance at its northern distributional limits may have been enhanced by human activities." Similarly, many of the northern Manitoba records described here were in roadside settings, especially ditches and gravel pits, but others were near natural creeks, beaver ponds, and lakeshores. The presence of treefrogs near the shore of Kaweenakumik Lake, in particular, shows that they do not have a purely roadside distribution in the area. It is therefore possible that the northernmost records represent a recent, linear range extension along highway rights-of-way (Highways 6 and 60 were constructed in the 1960s), but more likely that the treefrogs have simply not been noticed previously. There is no question, however, that the highways have modified the treefrogs' distribution at the local level, making them relatively easy to detect during the breeding season.

The Pas End Moraine seems to be a significant barrier to further northward range extension. This huge glacial feature extends from near the town of The Pas to Long Point on Lake Winnipeg, and includes the isthmus between Lake Winnipegosis and Cedar Lake. ${ }^{5}$ Katimik and Kaweenakumik Lakes lie immediately south of the moraine, and long sections of Hwy 60 
follow its southern slope. Much of the moraine is vegetated by mixed coniferous (spruce-tamarack-cedar) stands, whereas Gray Treefrogs seem to prefer moist, deciduous forest. Only one of the records described here, at South Morrison Creek, lies on the north slope of the moraine; a single treefrog was heard there on 19 June 2000 , and none on several subsequent visits. Searches around Grand Rapids and farther north along Hwy 6 have so far failed to turn up any treefrogs. North of the northwestmost part of Lake Winnipegosis, extensive low-lying black spruce bogs also appear to present a barrier to range extension.

The estimated range limit west of Lake Winnipegosis, as shown in Figure 1 , corresponds roughly to the drainage divide between: (a) rivers and creeks flowing from the eastern Duck Mountain area to the southern arm of Lake Winnipegosis (Duck Bay and Sagemace Bay), and (b) more northerly streams flowing from the Porcupine Hills and the northern part of Duck Mountain through the Swan River area to Swan Lake and thence to the northwestern arm of Lake Winnipegosis (Dawson Bay). ${ }^{2}$ The Manitoba Escarpment, which includes Duck Mountain and the Porcupine Hills, is a significant barrier to westward range extension, because of the reduced frost-free period and cooler summer climate at higher elevations. Nevertheless, there is extensive moist, deciduous woodland in some lower-lying areas adjoining these hilly regions. It may be worthwhile to seek Gray Treefrogs in such areas, in order to define the current range limit in more detail. Based on the findings described here, treefrogs would be most easily detected on warm, humid evenings between mid-June and early July.
In conclusion, my observations in the northern Interlake region show that the Gray Treefrog's range extends farther north than previously reported, and suggest that the range limits are still not fully known.

\section{Acknowledgements}

I thank Carol Scott for many helpful comments on a draft of this article, and all the naturalists cited for personal communications.

1. McALPINE, D.F., T.J. FLETCHER, S.W. GORHAM, and I.T. GORHAM. 1991. Distribution and habitat of the Tetraploid Gray Treefrog, Hyla versicolor, in New Brunswick and Eastern Maine. Canadian Field-Naturalist 105:526-529.

2. PRESTON, W.B. 1982. The Amphibians and Reptiles of Manitoba, Manitoba Museum of Man and Nature, Winnipeg, MB. 128 pp.

3. SCHUELER, F.W. and F.D. ROSS. 1986. Range extensions for Hylid frogs in Manitoba. Blue Jay 44:168-173.

4. TAYLOR, P. 2006. Calling periods for frogs and toads near Pinawa, Manitoba, with an update on Mink Frog and Green Frog distribution. Blue Jay 64:44-55.

5. TELLER, J.T. 1984. The Ice Age and its legacy. In: Tell er, J.T. (ed.). Natural Heritage of Manitoba: Legacy of the Ice Age. Manitoba Museum of Man and Nature, Winnipeg, MB.

6. WELLER, W.F. 2002. Hyla versicolor (Gray Treefrog) [in Kenora District, Ontario]. Herpetological Review 33:145 and 33:221.

7. WELLER, W. F., and D.M. GREEN. 1997. Checklist and current status of Canadian amphibians. In Green, D.M. (ed.), Amphibians in Decline: Canadian Studies of a Global Problem. Society for the Study of Amphibians and Reptiles, Herpetological Conservation No. 1. p. 309-328.

8. WELLER, W.F. and S.J. HECNAR. 2004. Hyla versicolor (Gray Treefrog) [in Thunder Bay District, Ontario]. Herpetological Review 35:404.

9. The North American Biodiversity Information Network is accessible online via the Species Access Canada portal of the Canadian Biodiversity Information Facility at http:// www.cbif.gc.ca/portal/digir-toc.php. 